Article

\title{
Gingerol Synergizes the Cytotoxic Effects of Doxorubicin against Liver Cancer Cells and Protects from Its Vascular Toxicity
}

\author{
Fahad A. Al-Abbasi ${ }^{1}$, Eman A. Alghamdi ${ }^{1}$, Mohammed A. Baghdadi ${ }^{1,2}$, \\ Abdulmohsin J. Alamoudi ${ }^{3}$, Ali M. El-Halawany ${ }^{4,5}$, Hany M. El-Bassossy ${ }^{3,6}$, \\ Ali H. Aseeri ${ }^{7}$ and Ahmed M. Al-Abd ${ }^{3,8, *}$ \\ 1 Department of Biochemistry, Faculty of Science, King Abdulaziz University, Jeddah 21523, Saudi Arabia; \\ alabassif@hotmail.com (F.A.A.-A.); mo0on_mo0ony@yahoo.com (E.A.A.); \\ m-baghdadi@hotmail.com (M.A.B.) \\ 2 Research Centre, King Faisal Specialist Hospital and Research Centre, Jeddah 21499, Saudi Arabia \\ 3 Department of Pharmacology and Toxicology, Faculty of Pharmacy, King Abdulaziz University, \\ Jeddah 21589, Saudi Arabia; abdulmohsin@outlook.com (A.J.A.); helbassossy@kau.edu.sa (H.M.E.-B.) \\ 4 Department of Natural Products and Alternative Medicine, Faculty of Pharmacy, King Abdulaziz University, \\ Jeddah 21589, Saudi Arabia; ahalawany2003@yahoo.com \\ 5 Pharmacognosy Department, Faculty of Pharmacy, Cairo University, Cairo 11562, Egypt \\ 6 Faculty of Pharmacy, Zagazig University, Zagazig 44519, Egypt \\ 7 Ministry of Health, Jeddah 21484, Saudi Arabia; alhaseeri@moh.gov.sa \\ 8 Department of Pharmacology, Medical Division, National Research Centre, Giza 12622, Egypt \\ * Correspondence: ahmedmalabd@pharma.asu.edu.eg; Tel.: +966-12-640-0000 (ext. 21125) \\ Academic Editor: Nancy D. Turner \\ Received: 5 June 2016; Accepted: 1 July 2016; Published: 8 July 2016
}

\begin{abstract}
Hydroxyphenylalkanes and diarylheptanoids possess potential therapeutic value in different pathophysiological conditions, such as malignancy. In the current study, naturally isolated hydroxyphenylalkane and diarylheptanoid compounds were investigated for potential chemo-modulatory effects in addition to potential vascular protective roles with doxorubicin. Diarylheptanoids showed stronger antioxidant effects, in comparison to hydroxyphenylalkanes, as demonstrated by DPPH assay and amelioration of $\mathrm{CCl}_{4}$-induced disturbed intracellular GSH/GSSG balance. Shogaol and 4'-methoxygingerol showed considerable cytotoxic effects against HCT116, HeLa, HepG2 and MCF7 cells, with IC 50 values ranging from 3.1 to $19.4 \mu \mathrm{M}$. Gingerol significantly enhanced the cytotoxic profile of doxorubicin against $\mathrm{HepG}_{2}$ and Huh7, cells decreasing its $\mathrm{IC}_{50} \mathrm{~s}$ by 10- and 4-fold, respectively. Cell cycle distribution was studied using DNA cytometry. Doxorubicin alone induced cell accumulation at S-phase and $\mathrm{G}_{2} / \mathrm{M}$-phase, while in combination with gingerol it significantly induced cell cycle arrest at the $\mathrm{G}_{2} / \mathrm{M}$-phase. Additionally, the vascular protective effect of gingerol against doxorubicin $(10 \mu \mathrm{M})$ was examined on isolated aortic rings. Co-incubation with 6-gingerol $(30 \mu \mathrm{M})$ completely blocked the exaggerated vasoconstriction and impaired vascular relaxation induced by doxorubicin. In conclusion, despite its relatively weak antioxidant properties, gingerol protected from DOX-induced vascular damage, apparently not through a ROS scavenging mechanism. Besides, gingerol synergized the cytotoxic effects of DOX against liver cancer cells without influencing the cellular pharmacokinetics.
\end{abstract}

Keywords: hydroxyphenylalkanes; diarylheptanoids; gingerol; doxorubicin; liver cancer; vascular protection 


\section{Introduction}

Grain of Paradise (Aframomum melegueta K. Schum, Zingiberaceae) is the only spice native to Africa and considered as an African panacea [1]. Seeds of A. melegueta were used, as a folk remedy, for the treatment of diarrhoea, and painful inflammatory conditions and in the control of postpartum haemorrhages [2]. Anti-ulcer, cytoprotective, antimicrobial, anti-nociceptive and aphrodisiac effects of the aqueous seed extract are also reported [3,4]. Phytochemical investigations of the plant seeds revealed the presence of paradol- and gingerol-like compounds, in addition to diarylheptanoids with hepatoprotective and estrogenic effects [5,6].

6-Gingerol is a major hydroxyphenylalkane isolated from A. melegueta and present in several plants belonging to the family Zingiberaceae, such as ginger and cardamom. The formerly mentioned plants are widely used in the Middle Eastern and Asian cuisine as a spice and everyday beverage. 6-Gingerol is reported to display several biochemical and pharmacological activities, such as cancer chemopreventive, anti-mutagenic, anti-apoptotic [7], anti-oxidant, anti-inflammatory [8], cardio- and hepatoprotective effects [5,9]. Gingerol is also known to inhibit the enzymes nitric oxide synthase and cyclo-oxygenase [10] and to suppress the expression of tumor necrosis factor alpha (TNF- $\alpha$ ) [11]. 6-Paradol, another major constituent of A. melegueta, is closely related in structure to gingerol with one hydroxyl less in the alkyl chain. It is reported to possess chemopreventive, antioxidant and anti-inflammatory effects [12]. Paradol and its derivatives induce apoptosis through a caspase-3-dependent mechanism [13]. In spite of its structure similarity to gingerol, paradol's biological activity is less explored than that of gingerol.

Diarylheptanoids are chemically characterized by the presence of an aryl-C7-aryl moiety. Diarylheptanoids from Pinus flexilis (E. James) possess protein kinase C inhibitory effects [14]. In addition, a cytotoxic diarylheptanoid was isolated from the roots of Juglans mandshurica (Maxim.) [15]. Diarylheptanoids with a carbonyl group at C-3, isolated from bark of black alder are also reported to inhibit the growth of resistant lung carcinoma. The active compounds were found to increase doxorubicin accumulation in cancer cells through modulation of P-gp activity [16].

The burden of neoplasia is increasing globally, with several millions deaths per year. Liver malignancies are the second most prevalent type of solid tumor, with an annual mortality of half a million among males and a similar number among females [17]. Doxorubicin (DOX) is a cytotoxic anthracycline used successfully for the treatment of several malignancies, such as liver cancer [18-20]. A major limitation for DOX treatment and a major cause of course treatment non-compliance is its intolerable cardiovascular side effects [21,22]. Several antioxidants were reported to have protective effect against doxorubicin-induced cardiovascular toxicity [9,23]. However, negative influence of free radical scavenging state might ameliorate the primary DOX anticancer properties [24-26]. In our previous work, resveratrol and didox (powerful antioxidants) marginally potentiated the effect of DOX against liver cancer cells and protected from its cardiotoxicity [27,28]. Apart from its toxicity, the efficacy of DOX is greatly affected by overexpression of ATP-dependent efflux pump P-glycoprotein (P-gp) [29]. It was reported previously that hydroxyphenylalkanes and diarylheptanoids are potential P-gp efflux pump inhibitors and hence might potentiate the activity of several P-gp substrates such as DOX [30]. In the current work, we isolated several naturally occurring hydroxyphenylalkanes and diarylheptanoids from A. melegueta K. Schum (Zingiberaceae). After rational preliminary biological screening of the isolated compounds, 6-gingerol was selected to protect from doxorubicin-induced vascular toxicity besides potentiating its anticancer properties against liver cancer cells.

\section{Results}

\subsection{Isolation and Structural Identification of Hydroxyphenylalkanes and Diarylheptanoids from A. melegueta}

The chloroform fraction of $A$. melegueta yielded three diarylheptanoids and six hydroxylphenyl -alkanes (Figure 1). The compounds were identified based on their ${ }^{1} \mathrm{H}$ - and ${ }^{13} \mathrm{C}-\mathrm{NMR}$ data (see Supplementary Materials) and by comparison with reported literature as follows: 
6-paradol (1) [31-34], 6-gingerol (2) [32], 8-dehydrogingerdione (3) [5], 6-shogaol (4) [33,34], 4'-methoxy-6-gingerol (5) [35], dihydro-6-paradol (6) [33], 3,5-diacetoxy-1-( $3^{\prime}, 4^{\prime}$-dihydroxylphenyl)-7(3",4" -dihydroxy-5"-methoxyphenyl)heptane, DIACHEP (7) [31], dihydrogingerenone C (8) [6], and dihydrogingerenone $\mathrm{A}(9)$ [6].<smiles>CCCCCCCC(=O)CCc1ccc(O)c(OC)c1</smiles><smiles>CCCCCCCC(=O)/C=C(O)/C=C/c1ccc(O)c(OC)c1</smiles><smiles>CCCCCC(O)CC(=O)CCc1ccc(OC)c(OC)c1</smiles><smiles>COc1cc(CCC(CC(CCc2ccc(O)c(O)c2)OC(C)=O)OC(C)=O)cc(O)c1O</smiles><smiles>CCCCCC(O)CC(=O)CCc1ccc(O)c(OC)c1</smiles><smiles>CCCCCC=CC(=O)CCc1ccc(O)c(OC)c1</smiles><smiles>CCCCCCCC(O)CCc1ccc(O)c(OC)c1</smiles><smiles>COc1cc(CCC(=O)CCCCc2ccc(O)c(O)c2)ccc1O</smiles><smiles>COc1cc(CCC(=O)CCCCc2ccc(O)c(O)c2)cc(O)c1O</smiles>

dihydrogingerenone A (9)

Figure 1. Compounds isolated from Aframomum melegueta.

\subsection{Anti-Oxidant Activity of Isolated Hydroxyphenylalkanes and Diarylheptanoids}

Hydroxyphenylalkanes and diarylheptanoids are known for their robust antioxidant activity. We tested their free radical scavenging activity using the DPPH assay. DIACHEP (7), dihydrogingerenone A (9), dihydrogingerenone C (8) and 4'-methoxy-6-gingerol (5) showed the strongest free radical scavenging activity, with $\mathrm{EC}_{50} \mathrm{~s}$ of less than $5 \mu \mathrm{M}$ and average free radical scavenging efficiencies higher than $40 \%$ (Figure 2A,B). Potent free radical scavenging hydroxyphenylalkanes and diarylheptanoids were tested in $\mathrm{CCl}_{4}$-challenged $\mathrm{HepG} 2$ cells. $\mathrm{CCl}_{4}$ significantly abolished the GSH-reductase activity in HepG2 cells. Only dihydrogingerenone A (9) and 4'-methoxy-6-gingerol (5) reversed $\mathrm{CCl}_{4}$-induced GSH reductase enzyme activity reduction (Figure 2C). Additionally, $\mathrm{CCl}_{4}$ significantly decreased the reduced $\mathrm{GSH}$ concentration; only dihydrogingerenone A (9) reversed $\mathrm{CCl}_{4}$-induced GSH reduction (Figure 2D). None of the hydroxyphenylalkanes and diarylheptanoids under investigation exerted any significant effect against GSH peroxidase enzyme (data not shown). 
A) DPPH scavenging efficiency (1.5-15 $\mu \mathrm{M})$

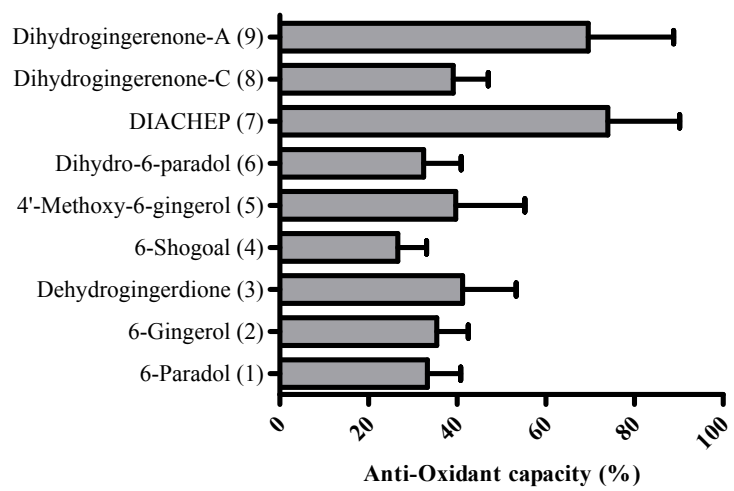

C) GSH-reductase acivity

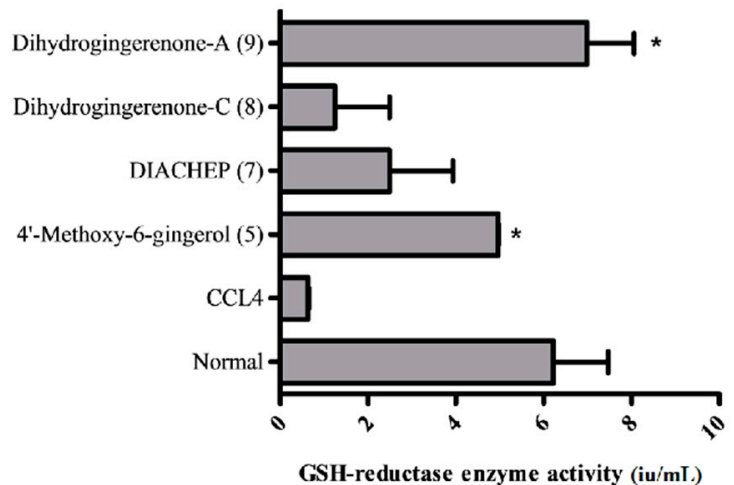

B) $\mathrm{EC}_{50}$ for DPPH scavenging activity

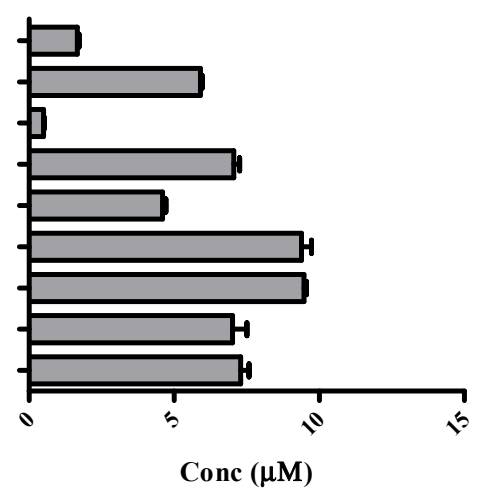

D) Intracellular antioxidant capacity

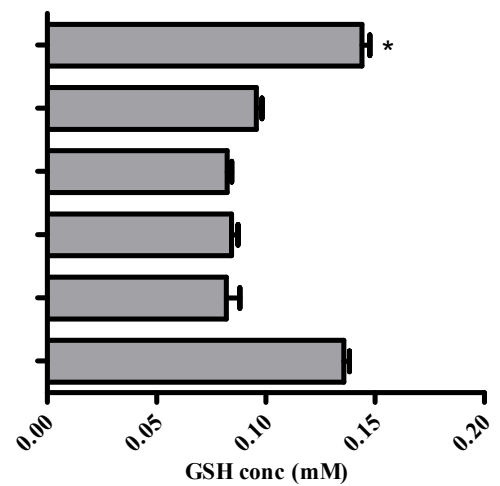

Figure 2. Antioxidant activity of isolated hydroxyphenylalkanes and diarylheptanoids was tested using a cell free system and with $\mathrm{HepG}_{2}$ cells. Antioxidant capacities of the test compounds were tested using the DPPH free radical scavenging assay; scavenging efficiency $(\mathbf{A})$ and $\mathrm{EC}_{50} \mathrm{~s}(\mathbf{B})$ were calculated over concentration range of 0.5 to $50 \mu \mathrm{M}$. GSH reductase enzyme activity (C) and GSH concentration (D) were determined in $\mathrm{CCl}_{4}$ challenged $\mathrm{HepG}_{2}$ cells. Data is presented as mean $\pm \mathrm{SD}$; $n=3$. *: significantly different from $\mathrm{CCl}_{4}$ treated group.

\subsection{Cytotoxicity Assessment of Hydroxyphenylalkanes and Diarylheptanoids}

The SRB-U assay was used to assess the cytotoxicity of nine naturally occurring hydroxyphenylalkanes and diarylheptanoids against four different tumor cell lines over a concentration range of $0.01-100 \mu \mathrm{M}$. The tested compounds showed variable cytotoxicities against the cell lines under investigation (HCT-116, HepG2, MCF-7 and HeLa cell lines). However, HepG2 cells were relatively more resistant, while HCT-116 was the most sensitive cell line.

In HCT-116 colorectal cancer cells, all tested compounds showed considerable cytotoxicities, with $\mathrm{IC}_{50} \mathrm{~s}$ ranging from $1.5 \mu \mathrm{M}$ to $12.6 \mu \mathrm{M}$. In addition, resistant fraction (R)-values for all hydroxyphenylalkanes and diarylheptanoids under investigation (except gingerol) were less than $15 \%$. It is worth mentioning that, despite the relatively low $\mathrm{IC}_{50}$ of gingerol $(1.5 \mu \mathrm{M})$, it suffered from considerably high resistance $(60.6 \%)$ within HCT-116 cells (Table 1$)$.

The HepG2 liver cancer cell line possessed the highest resistance to hydroxyphenylalkanes and diarylheptanoids amongst other tumor cell types. In HepG2 cells, only dihydro-6-paradol (6), 6-shogoal (4) and 4'-methoxy-6-gingerol (5) showed relatively potent cytotoxicity with $\mathrm{IC}_{50} \mathrm{~s}$ of $13.5 \mu \mathrm{M}, 18.7 \mu \mathrm{M}$ and $19.4 \mu \mathrm{M}$, respectively. However, dihydro-6-paradol (6) suffered from up to 50.2\% resistant fraction. Gingerol (2) showed moderate cytotoxicity against HepG2 cells with an $\mathrm{IC}_{50}$ of $71.9 \mu \mathrm{M}$. The rest of tested compounds did not show any notable cytotoxicity, with $\mathrm{IC}_{50}$ s higher than $100 \mu \mathrm{M}$ (Table 1). 
Table 1. Cytotoxicity parameters of some naturally occurring hydroxyphenylalkanes and diarylheptanoids against different solid tumor cell lines.

\begin{tabular}{|c|c|c|c|c|c|c|c|c|}
\hline \multirow{2}{*}{ Compound } & \multicolumn{2}{|c|}{ HCT-116 } & \multicolumn{2}{|c|}{ HepG2 } & \multicolumn{2}{|c|}{ MCF-7 } & \multicolumn{2}{|c|}{ HeLa } \\
\hline & $\begin{array}{l}\mathrm{IC}_{50} \\
(\mu \mathrm{M})\end{array}$ & $\begin{array}{c}\text { R-Value } \\
(\%)\end{array}$ & $\begin{array}{l}\mathrm{IC}_{50} \\
(\mu \mathrm{M})\end{array}$ & $\begin{array}{c}\text { R-Value } \\
(\%)\end{array}$ & $\begin{array}{l}\mathrm{IC}_{50} \\
(\mu \mathrm{M})\end{array}$ & $\begin{array}{c}\text { R-Value } \\
(\%)\end{array}$ & $\begin{array}{l}\mathrm{IC}_{50} \\
(\mu \mathrm{M})\end{array}$ & $\begin{array}{c}\text { R-Value } \\
(\%)\end{array}$ \\
\hline 6-Paradol (1) & 10.4 & 15.1 & $>100$ & N/A & 20.4 & 42.9 & 57.7 & 37.9 \\
\hline 6-Gingerol (2) & 1.5 & 60.6 & 71.9 & $\mathrm{~N} / \mathrm{A}$ & $>100$ & 85.6 & 15.5 & 43.8 \\
\hline Dehydrogingerdione (3) & 12.6 & $\mathrm{~N} / \mathrm{A}$ & $>100$ & N/A & 63.7 & N/A & 55.8 & 1.1 \\
\hline 6-Shogoal (4) & 3.1 & N/A & 18.7 & $\mathrm{~N} / \mathrm{A}$ & 7.5 & 1.1 & 10.2 & 1.1 \\
\hline 4'-Methoxy-6-gingerol (5) & 11.4 & 4.6 & 19.4 & N/A & 12.0 & N/A & 9.2 & 0.5 \\
\hline Dihydro-6-paradol (6) & 12.0 & N/A & 13.5 & 50.2 & 63.5 & 42.9 & 14.7 & 0.9 \\
\hline DIACHEP (7) & 11.2 & 4.1 & $>100$ & N/A & 61.5 & N/A & 20.2 & 0.94 \\
\hline Dihydrogingerenone-C (8) & 10.5 & 10.7 & $\mathrm{~N} / \mathrm{A}$ & 75.5 & 20.4 & 65.5 & 16.6 & 15.1 \\
\hline Dihydrogingerenone-A (9) & 12.2 & 7.8 & N/A & N/A & 59.4 & 0.7 & 17.5 & 5.5 \\
\hline
\end{tabular}

With respect to MCF-7 breast cancer cells, paradol (1), shogoal (4), dihydrogingerenone C (D 11) and $4^{\prime}$-methoxygingerol (5) showed considerable cytotoxicities, with $\mathrm{IC}_{50} \mathrm{~s}$ of 22.0, 20.4, 7.5, 20.4 and $12.0 \mu \mathrm{M}$, respectively. However, the resistant fractions for paradol (1) and dihydrogingerenone C (8) were higher than 40\%. DIACHEP (7), dihydro-6-paradol (6), dihydrogingerenone-A (9) and dehydrogingerdione (3) showed moderate cytotoxicities, with $\mathrm{IC}_{50}$ s ranging from $59.4 \mu \mathrm{M}$ to $63.7 \mu \mathrm{M}$. Dihydro-6-paradol (6) also suffered from resistance up to $42.9 \%$ in MCF-7 cells. Finally, gingerol showed weak cytotoxicity, with an $\mathrm{IC}_{50}$ higher than $100 \mu \mathrm{M}$ (Table 1).

Like HCT-116, the majority of hydroxyphenylalkanes and diarylheptanoids under investigation showed considerable cell killing effect toward HeLa cells. DIACHEP (7), 6-gingerol (2), dihydro-6paradol (6), 6-shogoal (4), dihydrogingerenone-A (9), dihydrogingerenone $C$ (8) and 4'-methoxy-6gingerol (5) killed HeLa cells with $\mathrm{IC}_{50}$ s equal to or less than $20 \mu \mathrm{M}$. Paradol (1) and dehydrogingerdione (3) were relatively weaker against HeLa cells with $\mathrm{IC}_{50} \mathrm{~s}$ of 57.7, 27.6 and $55.8 \mu \mathrm{M}$, respectively. HeLa did not show considerable resistance to the majority of hydroxyphenylalkanes and diarylheptanoids under investigation, with R-values equal to or less than 15\%. Only 6-gingerol (2) and 6-paradol (1) suffered from considerable resistance, with R-values of $43.8 \%$ and $37.9 \%$, respectively (Table 1 ).

\subsection{The Influence of Hydroxyphenylalkanes and Diarylheptanoids on the Cellular Pharmacokinetics}

Multidrug resistance in particular tumor types, such as solid tumors within the gastrointestinal tract, is highly attributed to impaired cellular pharmacokinetics and intracellular drug entrapment issues. The ability of hydroxyphenylalkanes and diarylheptanoids to enhance the cellular entrapment of P-glycoprotein substrates was tested within CaCo-2 colorectal cancer cells. Dihydro-6-paradol (6), 6-shogoal (4), dihydrogingerenone-A (9), dihydrogingerenone $C$ (8), and 4'-methoxy-6-gingerol (5) significantly increased the cellular entrapment of doxorubicin (P-gp probe) and increased its intracellular concentration from $113.1 \pm 2.6 \mathrm{pmole} / \mathrm{cell}$ to $123.7 \pm 3.0 \mathrm{pmole} / \mathrm{cell}, 127.0 \pm 2.8 \mathrm{pmole} / \mathrm{cell}$, $123.71 \pm 3.0 \mathrm{pmole} / \mathrm{cell}, 122.9 \pm 2.5 \mathrm{pmole} / \mathrm{cell}, 146.9 \pm 5.2 \mathrm{pmole} / \mathrm{cell}$ and $142.6 \pm 1.9 \mathrm{pmole} / \mathrm{cell}$, respectively (Figure 3A).

Further investigation for the sub-molecular interaction between the isolated compounds and P-gp subunits was undertaken using human recombinant P-gp membrane bound protein linked to ATPase enzyme subunit. Competitive P-gp inhibitors such as verapamil (VRP) are supposed to increase ATPase activity due to conformational changes and results in more ATP consumption (33.3\% less remaining ATP concentration compared to basal ATP consumption). On the other hand, direct ATPase inhibitors such as sodium vanadate would decrease ATP consumption (133.1\% more remaining ATP concentration compared to basal consumption condition). Only 6-shogoal (4) and 6-gingerol (2) showed pure ATPase inhibitory effects with $143.5 \%$ and $152.7 \%$ remaining ATP concentration, respectively (Figure 3B). On the other hand, DIACHEP (7), 6-paradol (1), dihydrogingerenone-A (9) and 4'-methoxy-6-gingerol (5) significantly decreased ATP remaining concentration to $75.5 \%, 78.2 \%, 50.2 \%, 61.9 \%$ and $43.2 \%$ of control level. This is indicative of increased ATP consumption and could be attributed to competitive 
P-gp inhibition (Figure 3B). Other hydroxyphenylalkanes and diarylheptanoids under investigation did not induce any significant change for ATP consumption rate. This might be attributed to lack of interaction with either subunit of P-gp molecules or to dual interaction with both subunits, yet dihydro-6-paradol (6), dihydrogingerenone $C$ (8) and dehydrogingerdione (3) significantly increased cellular entrapment of $\mathrm{P}$-gp probe. Accordingly, it is suggested that these compounds interact with both subunits of P-gp molecules. On the other hand, DIACHEP (7), and 6-paradol (1) did not exert any significant interaction with either subunit of P-gp molecules.
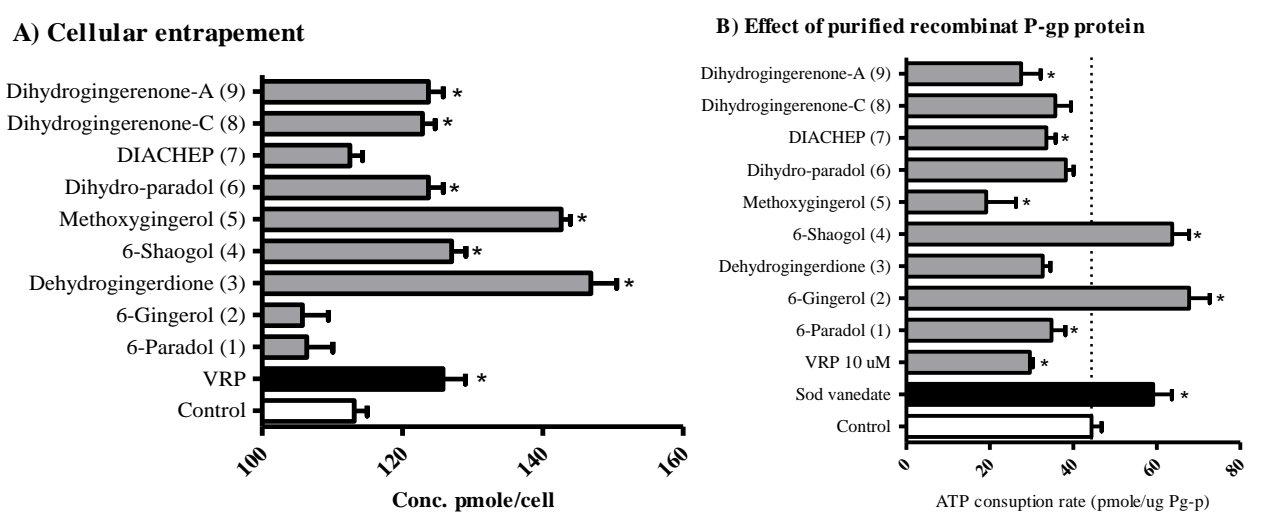

Figure 3. The effect of isolated compounds on the activity of P-glycoprotein efflux pump within CaCo-2 cells (A) and in cell free isolated recombinant P-gp protein (B). *: significantly different from control group.

\subsection{Chemomodulatory Effect of Gingerol on Doxorubicin within Liver Cancer Cells}

DOX exerts its cell killing effects via the generation of intracellular free radicals. Based on its moderate antioxidant activity (Figure 2), and moderate cytotoxic effects (Table 1), gingerol would be a good candidate to improve the activity of doxorubicin against liver cancer cells. Huh-7 cells were far more sensitive to DOX, compared to $\mathrm{HepG}_{2}$, with $\mathrm{IC}_{50}$ of $4.6 \pm 0.9 \mathrm{nM}$ and $680 \pm 60 \mathrm{nM}$, respectively. Gingerol exerts weaker cytotoxic effects against Huh-7 cells compared to $\mathrm{HepG}_{2}$ cells with $\mathrm{IC}_{50}$ 's of $103.1 \pm 3.0 \mu \mathrm{M}$ and $71.9 \pm 2.8 \mu \mathrm{M}$, respectively (Figure $4 \mathrm{~A}, \mathrm{~B}$ and Table 2). However, 6-gingerol synergistically improved the cytotoxic profile of DOX against both of these liver cancer cell lines. 6-Gingerol significantly decreased the $\mathrm{IC}_{50}$ 's of DOX form $680 \pm 60 \mathrm{nM}$ and $4.6 \pm 0.9 \mathrm{nM}$ to $67.4 \pm 9.1 \mathrm{nM}$ and $1.2 \pm 0.13 \mathrm{nM}$ in $\mathrm{HepG}_{2}$ and Huh-7 cells, respectively. The combination indices for equitoxic combination of gingerol and DOX within $\mathrm{HepG}_{2}$ and Huh-7 cells were 0.19 and 0.29, respectively (Table 2). It is worth mentioning that, gingerol combination with DOX did not influence the resistance fraction to DOX within either $\mathrm{HepG}_{2}$ or Huh-7 cells.
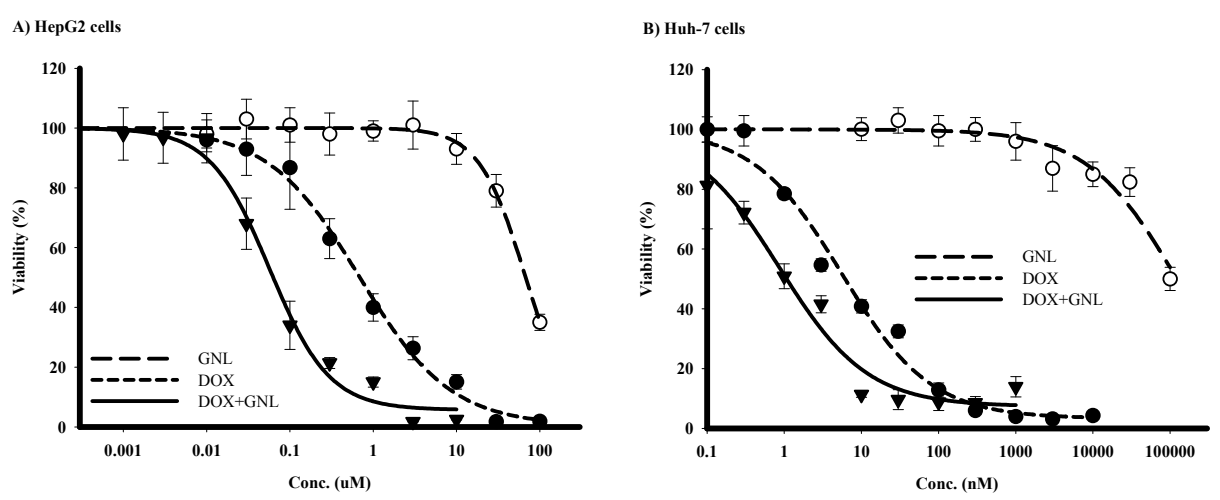

Figure 4. The effect of 6-gingerol (GNL) on the cytotoxicity of DOX in HepG2 (A) and Huh-7 (B) cell lines. Cells were exposed to serial dilution of DOX $(\bullet), G N L(\bigcirc)$ or their combination $(\boldsymbol{\nabla})$ for $72 \mathrm{~h}$. Cell viability was determined using SRB assay. 
Table 2. Effect of 6-gingerol (GNL) on the cytotoxicity parameters of DOX in liver cancer cells.

\begin{tabular}{ccccc}
\hline \multirow{2}{*}{ Treatment } & \multicolumn{2}{c}{ HepG $_{\mathbf{2}}$} & \multicolumn{2}{c}{ Huh-7 } \\
\cline { 2 - 5 } & IC $_{\mathbf{5 0}}$ & R-Value (\%) & IC $_{\mathbf{5 0}}$ & R-Value (\%) \\
\hline DOX & $680 \pm 60 \mathrm{nM}$ & $2.7 \pm 0.8$ & $4.6 \pm 0.9 \mathrm{nM}$ & $3.0 \pm 0.9$ \\
GNL & $71.9 \pm 2.8 \mu \mathrm{M}$ & $\mathrm{N} / \mathrm{A}$ & $103.1 \pm 3.0 \mu \mathrm{M}$ & $4.3 \pm 1.7$ \\
DOX + GNL & $67.4 \pm 9.1 \mathrm{nM}$ & $3.3 \pm 0.7$ & $1.2 \pm 0.13 \mathrm{nM}$ & $4.7 \pm 1.1$ \\
\hline CI-index/CI-value & \multicolumn{2}{c}{ Synergism/0.19 } & \multicolumn{2}{c}{ Synergism/0.29 } \\
\hline
\end{tabular}

\subsection{Cell Cycle Distribution Analysis of Liver Cancer Cells}

Cell cycle distribution determined using DNA flow cytometry was used to investigate the nature of the interaction between DOX and gingerol. In $\mathrm{HepG}_{2}$ cells, gingerol significantly decreased the cell population is S-phase from $15.5 \% \pm 0.7 \%$ to $12.7 \% \pm 1.3 \%$. DOX treatment alone significantly increased the cell population in $\mathrm{G}_{2} / \mathrm{M}$ phase (from $7.1 \% \pm 0.7 \%$ to $14.6 \% \pm 3.1 \%$ ) with a reciprocal decrease in the S-phase cell population (from $15.5 \% \pm 0.7 \%$ to $12.5 \% \pm 1.2 \%$ ) (Figure $5 \mathrm{~A}-\mathrm{C}, \mathrm{E}$ ). The combination of DOX with gingerol induced significant cell cycle arrest at the $\mathrm{G}_{2} / \mathrm{M}$ phase $(17.4 \% \pm 2.4 \%)$ compared to the control group $(7.1 \% \pm 0.7 \%)$. The induced $\mathrm{G}_{2} / \mathrm{M}$ cell phase arrest was accompanied by reciprocal decrease in the non-proliferating cell population $\left(\mathrm{G}_{0} / \mathrm{G}_{1}\right.$-phase) from $77.4 \% \pm 1.0 \%$ to $68.9 \% \pm 3.0 \%$ (Figure 5A,D,E).
A) Control
B) GNL
C) DOX
D) $\mathrm{DOX}+\mathrm{GNL}$

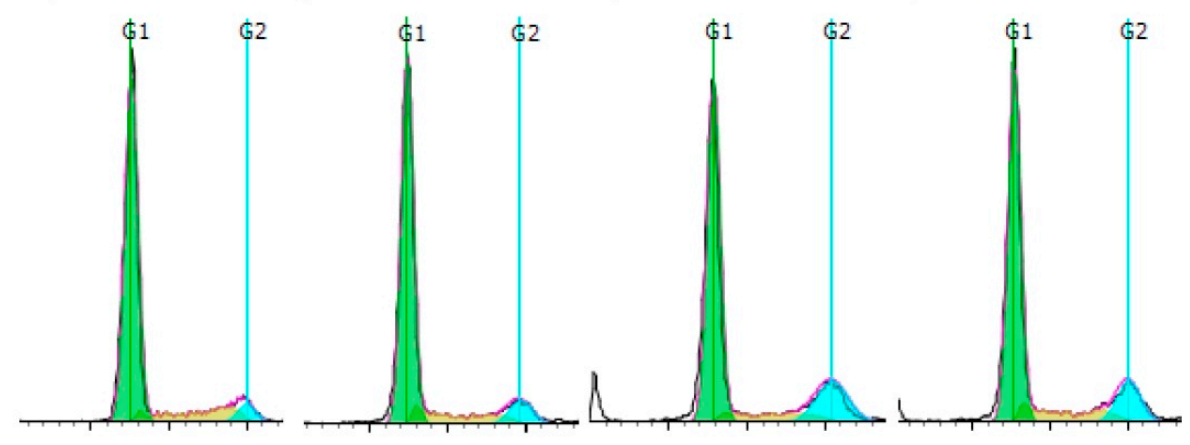

E) Cell cycle distribution

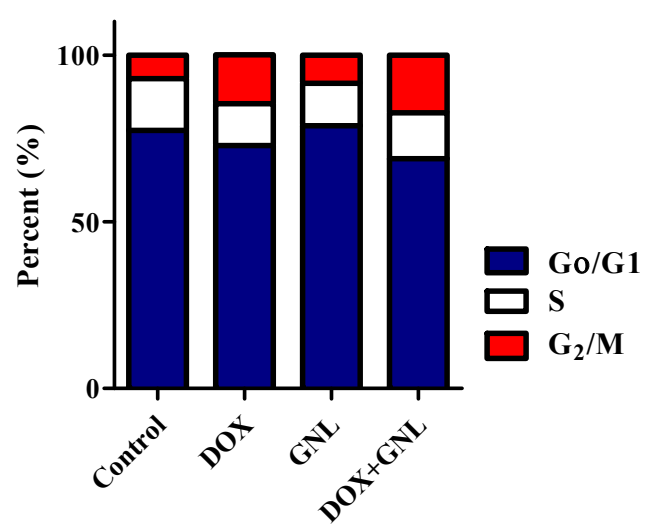

F) Apoptosis

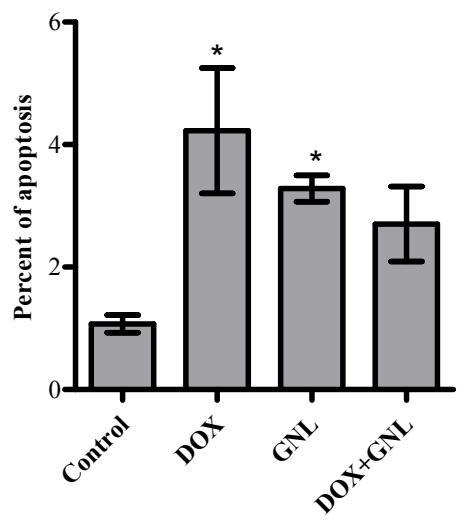

Figure 5. Effect of 6-gingerol (GNL) on the cell cycle distribution of HepG2 cells. The cells were exposed to GNL (B); DOX (C); or combination of GNL and DOX (D) for $24 \mathrm{~h}$ and compared to control cells (A); Cell cycle distribution was determined using DNA cytometry analysis and different cell phases were plotted (E) as percentage of total events; Sub-G cell population was taken as representative of late apoptosis/necrosis and was plotted as percent of total events $(\mathbf{F})$. Data is presented as mean \pm SD; $n=3$. *: significantly different from control group. 
Finally, exposure of HepG2 cells to DOX or gingerol alone for $24 \mathrm{~h}$ resulted in significant cell death observed by elevated pre-G cell population form $1.1 \% \pm 0.2 \%$ to $4.2 \% \pm 1.0 \%$ and $3.3 \% \pm 0.2 \%$, respectively. Gingerol combination with DOX did not inhibit DOX-induced cell kill, where no significant change in pre-G cell population was observed after combination treatment compared to cells treated with DOX alone (Figure 5F).

With respect to Huh-7 cells, gingerol significantly decreased the cell population in $\mathrm{G}_{0} / \mathrm{G}_{1}$-phase (from $77.4 \% \pm 1.0 \%$ to $52.6 \% \pm 2.0 \%$ ) with a reciprocal increase in both S-phase (from $15.5 \% \pm 0.4 \%$ to $19.6 \% \pm 1.2 \%$ ) and $i_{2} / \mathrm{M}$ phase (from $7.1 \% \pm 0.7 \%$ to $27.8 \% \pm 3.2 \%$ ) cell populations (Figure 6A,B,E). DOX alone significantly arrested cells at $\mathrm{G}_{2} / \mathrm{M}$-phase $(77.0 \% \pm 2.0 \%$ ) compared to control $(7.1 \% \pm 0.7 \%)$; with reciprocal abolishment for cells in $\mathrm{G}_{0} / \mathrm{G} 1$-phase from $77.4 \% \pm 1.0 \%$ to $8.9 \% \pm 0.1 \%$ (Figure $6 \mathrm{~A}, \mathrm{C}, \mathrm{E}$ ). The combination of gingerol with DOX similarly arrested cells at $\mathrm{G}_{2} / \mathrm{M}$-phase $(76.2 \% \pm 0.9 \%)$ compared to control $(7.1 \% \pm 0.7 \%)$; with reciprocal abolishment for cells in $\mathrm{G}_{0} / \mathrm{G} 1$-phase from $77.4 \% \pm 1.0 \%$ to $11.8 \% \pm 1.0 \%$ (Figure $6 \mathrm{~A}, \mathrm{D}, \mathrm{E}$ ). Finally, exposure of Huh-7 cells to DOX as well as combination of DOX with gingerol for $24 \mathrm{~h}$ resulted in significant cell death observed by an elevation of the pre-G cell population from $1.1 \% \pm 0.2 \%$ to $2.3 \% \pm 0.3 \%$ and $2.2 \% \pm 0.2 \%$, respectively (Figure 6F).

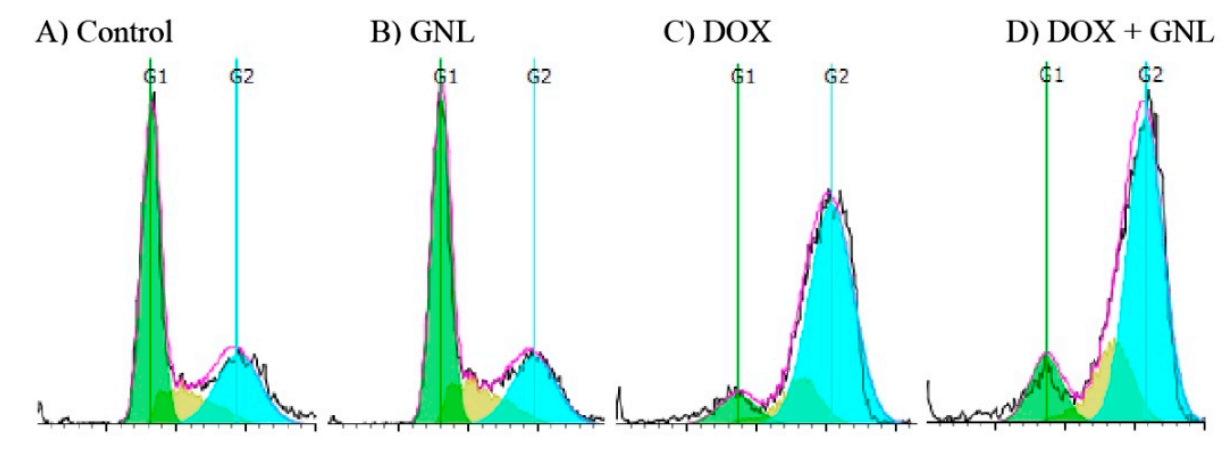

E) Cell cycle distribution

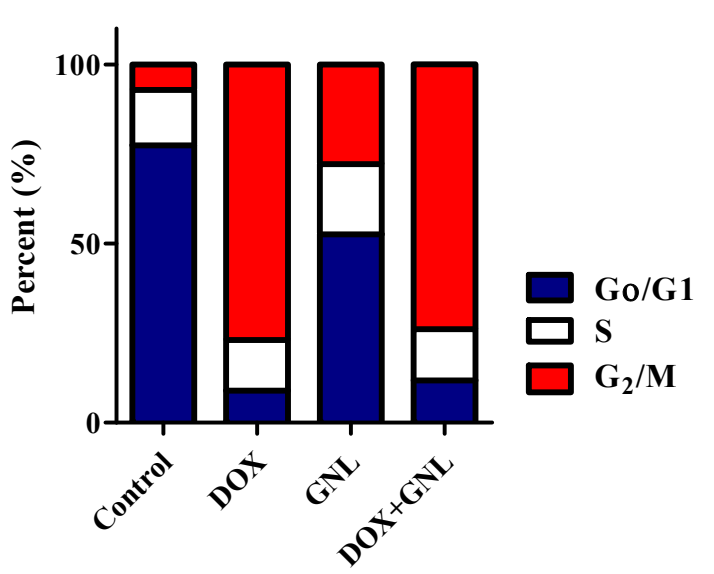

F) Apoptosis

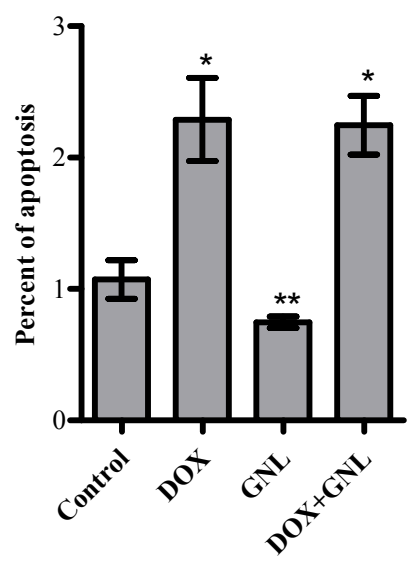

Figure 6. Effect of GNL on the cell cycle distribution of Huh-7 cells. The cells were exposed to GNL (B); DOX (C); or combination of GNL and DOX (D) for $24 \mathrm{~h}$ and compared to control cells (A); Cell cycle distribution was determined using DNA cytometry analysis and different cell phases were plotted (E) as percentage of total events; Sub-G cell population was taken as representative of late apoptosis/necrosis and was plotted as percent of total events $(\mathbf{F})$. Data is presented as mean $\pm \mathrm{SD} ; n=3$. *: significantly different from control group; ${ }^{* *}$ : significantly different from DOX group. 


\subsection{Gingerol Protects from DOX Induced Vascular Toxicity}

The current study showed that aortae isolated from normal animals exposed to doxorubicin $(10 \mu \mathrm{M}, 1 \mathrm{~h})$ exhibited exaggerated vasoconstriction in response to PE $\left(10^{-9}\right.$ to $\left.10^{-5} \mathrm{M}\right)$, compared to unexposed aortae. This enhancement of vasoconstriction was statistically significant $(p<0.05)$ at PE concentrations of $3 \times 10^{-5}$ and $10^{-5} \mathrm{M}$ (Figure $7 \mathrm{~B}$ ). Thirty minutes of incubation with 6-gingerol $(0.3-30 \mu \mathrm{M})$ alleviated this DOX-induced exaggerated vasoconstriction of aortae in a concentration-dependent manner. The inhibition of PE $\left(10^{-5} \mathrm{M}\right)$-induced contraction was significant at both tested concentrations of 6-gingerol (10 and $30 \mu \mathrm{M})$ with PE concentrations of $3 \times 10^{-5.5}$ and $10^{-5} \mathrm{M}$. The highest concentration of 6-gingerol $(30 \mu \mathrm{M})$ normalized the exaggerated contraction response to PE back to normal control value (Figure 7B).

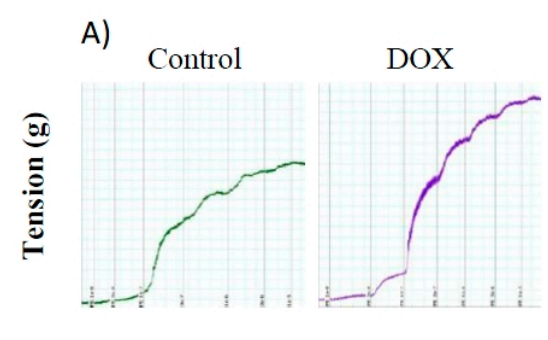

B) Vascular contraction

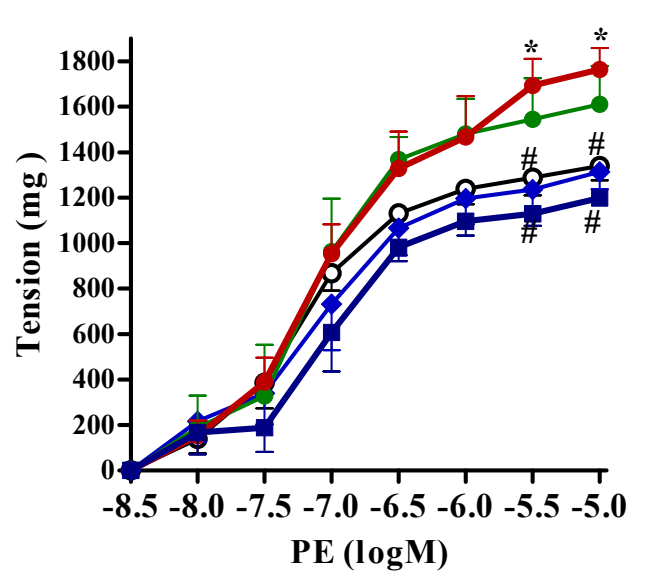

$\mathrm{DOX} / \mathrm{GNL}(3 \mu \mathrm{M})$

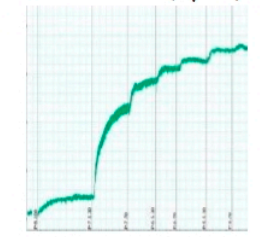

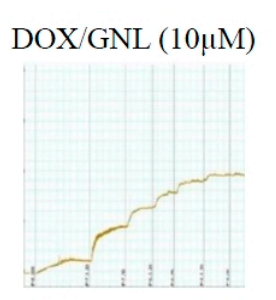

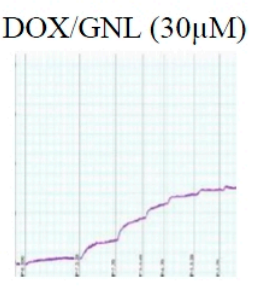

C) Vascular relaxation

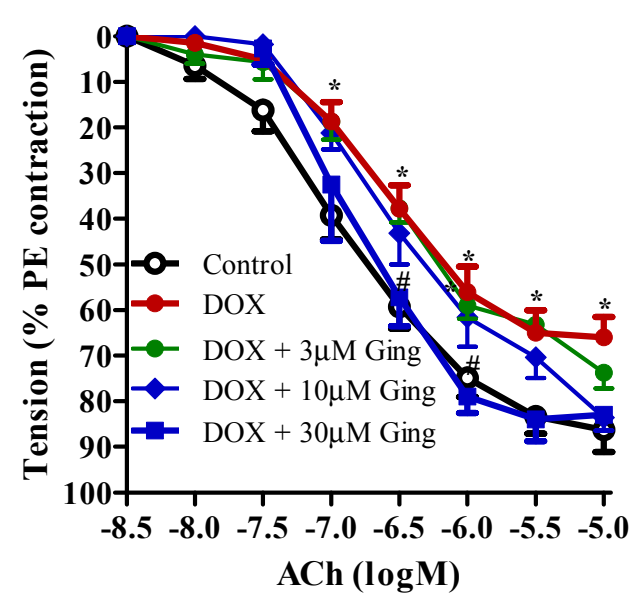

Figure 7. Effect of in vitro incubation with 6-gingerol $(3,10$ and $30 \mu \mathrm{M})$ on doxorubicin (DOX, $10 \mu \mathrm{M}$ )-induced exaggerated vasoconstriction to phenylephrine (PE), (A,B) and impaired vasodilation to acetylcholine $(\mathrm{ACh})(\mathrm{C})$. A Data is presented as mean $\pm \mathrm{SD} ; n=6-8$. $^{*}$ : significantly different from control group; \#: significantly different from DOX treated group.

Aortae exposed to DOX showed impaired vasodilation compared to unexposed aortae and this impaired relaxation was significant at ACh concentrations of $10^{-7}$ to $10^{-5} \mathrm{M}$. This impaired relaxation was alleviated by incubation with 6-gingerol in a concentration dependent manner and this alleviation was significant at the $30 \mu \mathrm{M}$ concentration of 6-gingerol tested with PE concentrations of $3 \times 10^{-6.5}$ and $10^{-6} \mathrm{M}$ (Figure 7B).

\section{Discussion}

Natural products are eternal sources of active compounds. The therapeutic use of natural products has escalated from folk use of the whole plant or unprocessed natural entities [36] to the use of standardized extracts [37], followed by the isolation of specified compounds with defined molecular structures [38]. Grouping compounds of similar molecular structure sharing close pharmacological activity could shed light on structure-activity relationships and stimulate chemists to initiate the lead optimization process $[39,40]$. Herein, we isolated several structurally related hydroxyphenylalkane 
and diarylheptanoid compounds and assessed their potential cytotoxic and chemomodulatory effects, in addition to confirming their documented antioxidant activity.

All hydroxyphenylalkanes and diarylheptanoids under investigation showed considerable antioxidant activity in cell free systems and within $\mathrm{HepG}_{2}$ cells. However, diarylheptanoids could be considered more potent than hydroxyphenylalkanes in free radical scavenging capacity, as well as in restoring cellular GSH/GSSG balance. This might be attributed to the occurrence of an extra aromatic system in diarylheptanoids [41,42]. Some compounds such as DIACHEP (7) and dihydrogingerenone C (8) possessed free radical scavenging activity but failed to restore cellular GSH balance. This might be attributed to their slow cellular internalization [43]. Gingerol possessed moderate to weak antioxidant capacity compared to the rest of hydroxyphenylalkanes and diarylheptanoids. Our previous study showed that the vascular protective effects of gingerol might be attributed to direct vasodilatation and nitric oxide generation rather than free radical scavenging mechanism [44]. Besides, gingerol is reported as cardioprotective agent; and particularly against DOX-induced cardiac damage [9,45].

Hydroxyphenylalkanes and diarylheptanoids showed moderately potent cytotoxicity in the current work, with $\mathrm{IC}_{50} \mathrm{~s}$ above $1 \mu \mathrm{M}$ in all tested cell lines. However, these compounds showed preferable cytotoxicity against HCT-116 colorectal cancer cells. This might be partly attributed to the P-gp inhibitory effect of this group of compounds which could have induced excessive intracellular accumulation and auto-enhancement effects [46,47]. Although, P-gp is expressed in almost all gastrointestinal-related tumors [48,49], similar efficacies were not found against $\mathrm{HepG}_{2}$ liver cancer cells. This might be attributed to the mutated form of P-gp protein expressed in liver cancer [50].

The ability of hydroxyphenylalkanes and diarylheptanoids to interrupt the function of P-gp was tested functionally and at the sub-molecular level. Most of compounds under investigation improved the cellular pharmacokinetics of P-gp probe, while only 6-shogoal and 6-gingerol specifically inhibited the P-gp ATPase subunit. Other hydroxyphenylalkanes and diarylheptanoids are expected to inhibit the P-gp efflux pump via non-specific competitive binding or mixed ATPase inhibition/competitive binding. It would be better in terms of structure-activity relationship and lead optimization to design specific P-gp ATP-ase inhibitors rather than non-specific competitive binding inhibitors [30]. Interestingly, gingerol did not enhance the cellular entrapment of DOX within CaCo-2 cells. Besides the high expression of $\mathrm{P}$-gp within $\mathrm{CaCo}-2$ cells, it might be also explained by the abundance of other types of efflux proteins on the cell membrane of colorectal cancer cells such as MRP1, MRP2 or others [47].

Antioxidants might protect from the side effects and toxic manifestations of a wide variety of anticancer drugs such as doxorubicin [51,52]. However, substantial worries about the negative effect of these agents on the primary anticancer properties of chemotherapies cannot be discounted [26]. Herein and amongst this group of compounds, gingerol was selected for further investigation in the context of influencing the cytotoxicity of doxorubicin against liver cancer cells besides its protective effects against doxorubicin-induced vascular toxicity. Gingerol significantly synergized the cytotoxic effects of doxorubicin against two different liver cancer cells. In previous studies from our group different antioxidants (natural or synthetic) marginally enhanced the cytotoxic profile of doxorubicin, producing only additive drug interaction $[27,28]$. This might be supported by the weak antioxidant activity of gingerol. However, it cannot be attributed to enhanced cellular internalization of doxorubicin or cellular pharmacokinetic interaction. HepG2 cells also express different types of efflux pump proteins such as P-gp and BCRP [53] that might compensate for the specific P-gp ATPase inhibition activity of gingerol.

Pharmacodynamic interactions between doxorubicin and gingerol were studied using cell cycle distribution analysis. In Huh-7 cells, gingerol significantly induced cell accumulation in the S-phase as well as the $\mathrm{G}_{2} / \mathrm{M}$-phase. Doxorubicin preferably intercalates with cellular DNA while cells are in either S-phase or $\mathrm{G}_{2} / \mathrm{M}$-phase inducing cell cycle arrest at $\mathrm{G}_{2} / \mathrm{M}$-phase, also called mitotic crises/catastrophe [54]. It was reported that agents inducing S-phase accumulation sensitize tumor cells to the killing effect of doxorubicin [55]. In contrast to Huh-7, $\mathrm{HepG}_{2}$ did not respond to gingerol treatment by S-phase accumulation; gingerol exerted clear antiproliferative effect accumulating 
cells at the $\mathrm{G}_{0} / \mathrm{G}_{1}$-phase. This explains the relatively weaker combined effect of gingerol and doxorubicin against $\mathrm{HepG}_{2}$ cells relative to Huh-7 cells. Luckily; gingerol did not hinder the activity of doxorubicin against $\mathrm{HepG}_{2}$ cells [56,57]. In other words, the synergism of gingerol with doxorubicin $(\mathrm{CI}$-value $=0.19)$ against Huh-7 cells could be attributed to gingerol-induced cell cycle synchronization in the S-phase resulting in excessive sensitivity to doxorubicin. However, the weaker synergism $(\mathrm{CI}$-value $=0.29)$ between gingerol and doxorubicin in $\mathrm{HepG}_{2}$ cells could be attributed to combined but independent antiproliferative and cytotoxic effects of gingerol and doxorubicin, respectively. Further molecular investigations to completely reveal the underlying possible pharmacodynamic interaction mechanisms between gingerol and doxorubicin in liver cancer cells are recommended.

Additionally, gingerol significantly protected against doxorubicin-induced vascular damage, in terms of restoring normal vascular contraction and relaxation. Our previous studies proved the protective effects of gingerol from doxorubicin induced cardiac damage at cardiomyocyte level [9]. Besides, we previously showed protective effects for gingerol against vascular complications of metabolic syndrome that was attributed to gingerol mediated vasodilatation [44]. In continuation of this research line, we presented experimental evidence for the functional protection of gingerol against doxorubicin induced vascular damage without ameliorating its inherent cytotoxicity against liver cancer cells.

\section{Materials and Methods}

\subsection{Drugs and Chemicals}

Verapamil (VRP), and Trypan Blue were purchased from Sigma Chemical Co. (St. Louis, MO, USA). Sulforhodamine-B (SRB) was purchased from Biotium Inc. (Hayward, CA, USA). Penicillin streptomycin and trypsin were purchased from Gibco (Grand Island, NY, USA). Phosphate buffer saline (PBS) was purchased from Becton Dickinson (Fullerton, CA, USA). RPMI-1640 media, DMEM media, fetal bovine serum (FBS), and other cell culture materials were purchased from ATCC (Houston, TX, USA). Other reagents were of the highest analytical grade.

\subsection{General Experimental Procedures}

Nuclear magnetic resonance (NMR, H, $400 \mathrm{MHz} ;{ }^{13} \mathrm{C}, 100 \mathrm{MHz}$ ) spectra were recorded on a JHA-LAA 400 WB-FT spectrometer (Jeol Co., Tokyo, Japan), the chemical shifts are presented as ppm with tetramethylsilane as an internal standard. TLC was carried out on pre-coated silica gel 60 F254 (0.25 mm, Merck; Darmstadt, Germany) and RP-18 F254S (0.25 mm, Merck Co.). Column chromatography (CC) was carried out on a BW-820MH silica gel, Wakosil C-300 silica gel $(40-63 \mu \mathrm{m})$ (Wako Chem. Co., Osaka, Japan). Medium pressure liquid chromatography (MPLC) was performed on LiChroprep RP-18 (size A and B; Merck Co.).

\subsection{Plant Material}

Seeds of A. melegueta were purchased from the Harraz herbal store (Cairo, Egypt), and were identified by Assistant Prof. Dr. Sherif El-Khanagry, Agriculture Museum, El-Dokki, Cairo, Egypt. A voucher specimen has been kept in the herbarium of the Department of Pharmacognosy, Faculty of Pharmacy, Cairo University.

\subsection{Extraction and Isolation of Compounds from A. melegueta}

Seeds of A. melegueta ( $2.5 \mathrm{~kg}$ ) were pulverized and extracted with $\mathrm{MeOH}(1 \mathrm{~L})$ by cold maceration for three successive days. The pooled $\mathrm{MeOH}$ extracts were evaporated under vacuum to give a brown residue $(130 \mathrm{~g})$. The $\mathrm{MeOH}$ extract was suspended in water $(500 \mathrm{~mL})$ and fractionated using $\mathrm{CHCl}_{3}(1$ $\mathrm{L} \times 3)$ and the pooled fractions were evaporated under vacuum to yield chloroform fraction $(90 \mathrm{~g})$. The $\mathrm{CHCl}_{3}$ fraction was purified on silica gel column $(70 \mathrm{~cm} \times 5 \mathrm{~cm})$ and eluted gradiently with hexane-EtOAc (5\%-80\%). The obtained fractions were pooled into ten sub-fractions $1-10$. 
Fraction $1(15 \mathrm{~g})$ was purified on a silica gel column $(40 \mathrm{~cm} \times 3 \mathrm{~cm})$ eluted with hexane-EtOAc (9.5:0.5 $v / v)$ to yield compound $1(8 \mathrm{~g})$. Fraction $3(6.5 \mathrm{~g})$ was chromatographed on a silica gel column $(20 \mathrm{~cm} \times 2.5 \mathrm{~cm})$ and eluted with hexane-EtOAc $(9: 1 \mathrm{v} / v)$ yielding $2(2.5 \mathrm{~g})$ and six subfractions. Sub-fraction 3-5 (1 g) was purified using a MPLC RP-18 column (size B) eluted with $\mathrm{MeOH}-\mathrm{H}_{2} \mathrm{O}$ $(8: 2 v / v)$ to yield compounds $3(4 \mathrm{mg}), \mathbf{4}(25 \mathrm{mg})$ and $5(5 \mathrm{mg})$. Sub-fraction 3-8 $(800 \mathrm{mg})$ was purified using a MPLC column size B eluted with $\mathrm{MeOH}-\mathrm{H}_{2} \mathrm{O}(5: 5-7: 3 v / v)$ to obtain compound 6 (10 mg). Fraction $9(13 \mathrm{mg})$ was chromatographed on a silica gel column $(40 \mathrm{~cm} \times 4 \mathrm{~cm})$ and eluted with a hexane-EtOAc (9:1-5:5 $v / v)$ gradient to yield sub-fractions 9-1-9-3. Sub-fraction 9-3 was purified on a silica gel column $(25 \mathrm{~cm} \times 2 \mathrm{~cm})$ eluted with hexane-EtOAc $(6: 4 \mathrm{v} / v)$ affording compounds $7(1 \mathrm{~g})$ and $8(10 \mathrm{mg})$. The remainder of the fraction was applied to a MPLC column RP-18 (size A) eluted with $\mathrm{MeOH}-\mathrm{H}_{2} \mathrm{O}(6: 4 v / v)$ to afford compound $9(20 \mathrm{mg})$.

\subsection{Determining the Antioxidant Activity of Test Compounds Using Cell-Free System (DPPH Assay)}

The antioxidant activity of the test compounds was evaluated using the DPPH radical scavenging method. Serial concentrations $(0.5-50 \mu \mathrm{M})$ of test compounds were prepared with $0.4 \mathrm{mg} / \mathrm{mL}$ solution of DPPH in pure ethanol and left in the dark for $30 \mathrm{~min}$. Absorbance at $520 \mathrm{~nm}$ was then measured and average free radical scavenging activity for each compound was calculated. Besides, $\mathrm{EC}_{50}$ were calculated from linear best fit regression analysis.

\subsection{Cell Culture}

Six different human solid tumor cell lines were used; colorectal cancer cell lines (HCT-116 and CaCo-2), cervical cancer cell line (HeLa), hepatocellular cancer cell lines (HepG2 and Huh-7), and breast cancer cell line (MCF-7). All Cell lines were obtained from VACSERA (Giza, Egypt). Cell lines were maintained in RPMI-1640 or DMEM media containing $100 \mathrm{U} / \mathrm{mL}$ penicillin; $100 \mu \mathrm{g} / \mathrm{mL}$ streptomycin, and supplemented with $10 \%$ heat-inactivated fetal bovine serum (FBS). Cells were propagated in a humidified cell culture incubator with $5 \%(v / v) \mathrm{CO}_{2}$ at $37^{\circ} \mathrm{C}$.

\subsection{Determining the Antioxidant Activity of Test Compounds within HepG2 Cells}

To assess the potential free radical scavenging capacity of test compounds within the intracellular compartment, $\mathrm{HepG}_{2}$ cells $\left(10^{5}\right.$ cells) were challenged with $\mathrm{CCl}_{4}(40 \mathrm{mM})$ alone or with potentially active hydroxyphenylalkanes and diarylheptanoid compounds $(5 \mu \mathrm{M})$ for $4 \mathrm{~h}$. Media was collected and level of reduced glutathione (GSH) as well as the activity of glutathione reductase and peroxidase enzymes were measured as previously described [58-60].

\subsection{Cytotoxicity Assessment}

The cytotoxicity of the isolated compounds was tested against HCT-116, HeLa, HepG2, Huh-7 and MCF-7 cells by SRB assay as previously described [61]. Briefly, exponentially growing cells were collected using $0.25 \%$ Trypsin-EDTA and seeded in 96-well plates at 1000-2000 cells/well. Cells were treated with the isolated compounds for $72 \mathrm{~h}$ and subsequently fixed with TCA $(10 \%)$ for $1 \mathrm{~h}$ at $4{ }^{\circ} \mathrm{C}$. After several washings with water, cells were exposed to $0.4 \%$ SRB solution for 10 minutes at room temperature in dark place and subsequently washed with $1 \%$ glacial acetic acid. After the plates drying overnight, Tris- $\mathrm{HCl}$ was used to dissolve the SRB stained cells and color intensity was measured at $540 \mathrm{~nm}$ with ELISA microplate reader.

\subsection{Data Analysis}

The dose-response curves were analyzed as previously described [62] using the $E_{\max }$ model (Equation (1)):

$$
\% \text { Cell viability }=(100-\mathrm{R}) \times\left(1-\frac{[\mathrm{D}]^{\mathrm{m}}}{\mathrm{K}_{\mathrm{d}}^{\mathrm{m}}+[\mathrm{D}]^{\mathrm{m}}}\right)+\mathrm{R}
$$


where $\mathrm{R}$ is the residual unaffected fraction (the resistance fraction), [D] is the drug concentration used, $\mathrm{K}_{\mathrm{d}}$ or $\mathrm{IC}_{50}$ is the drug concentration that produces a $50 \%$ reduction of the maximum inhibition rate and $\mathrm{m}$ is a Hill-type coefficient. Absolute $\mathrm{IC}_{50}$ is defined as the drug concentration required to reduce absorbance by $50 \%$ of that of the control (i.e., $\mathrm{K}_{\mathrm{d}}=$ absolute $\mathrm{IC}_{50}$ when $\mathrm{R}=0$ and $\mathrm{E}_{\max }=100-\mathrm{R}$ ).

\subsection{The Influence of the Naturally Hydroxyphenylalkanes and Diarylheptanoids on the Cellular Pharmacokinetics of Doxorubicin (DOX)}

To assess the effect of hydroxyphenylalkanes and diarylheptanoids on cellular pharmacokinetics in colorectal cancer cells, their effect on the efflux pumping activity of P-gp was evaluated. Herein, doxorubicin (DOX) was used as P-gp fluorescent substrate. Intracellular DOX concentration was determined with and without co-exposure with hydroxyphenylalkanes and diarylheptanoids and compared to VRP as standard P-gp inhibitor (positive control). Briefly, exponentially proliferating CaCo-2 cells were plated in 6-well plates at plating density of $10^{5}$ cells $/$ well. Cells were exposed to equimolar concentration of DOX $(10 \mu \mathrm{M})$ and test compounds or VRP for $24 \mathrm{~h}$ at $37{ }^{\circ} \mathrm{C}$ and subsequently, extracellular DOX-containing media was washed three times in ice cold PBS. Intracellular DOX was extracted after cell lysis by sonication with saturated aqueous solution of $\mathrm{ZnSO}_{4}(100 \mu \mathrm{L})$, acetonitril $(500 \mu \mathrm{L})$ and acetone $(250 \mu \mathrm{L})$ for $20 \mathrm{~min}$ at $37^{\circ} \mathrm{C}$. After centrifugation, clear supernatant solution was collected and DOX concentration was measured spectroflourometrically at $\lambda_{\text {ex/em }}$ of 482/550 nm. DOX concentration was normalized based on cell number [28].

\subsection{Determining Sub-Molecular Interaction Characteristics between P-gp Protein and Naturally Occurring Hydroxyphenylalkanes and Diarylheptanoids}

P-gp inhibitors block its efflux pumping activity via either competitive binding or inhibiting P-gp ATPase activity. Human recombinant membrane bound P-gp protein attached with ATPase subunit (Pgp-Glo ${ }^{\mathrm{TM}}$ Assay Systems, Promega Corporation, Madison, WI, USA) was used to determine the mechanism of P-gp inhibition via determining ATP consumption rate. Briefly, test compounds $(10 \mu \mathrm{M})$ were incubated with Pgp-Glo ${ }^{\mathrm{TM}}$ assay systems according to manufacturer protocol. Rate of ATP consumption was calculated by measuring luminescent signal of the unmetabolized ATP via firefly luciferase system. Compound which covalent bind to P-gp molecule is supposed to stimulate ATPase subunit and increase ATP consumption; while ATPase inhibitor compounds would decrease ATPase subunit activity and decrease ATP consumption rate. Verapamil and sodium vanadate were used as positive controls (covalent binding and ATPase inhibitors, respectively). ATP consumption was expressed as remaining ATP concentration and normalized per P-gp protein concentration (pmole ATP/ $\mu g$ P-gp protein).

\subsection{Chemomodulatory Effect of Gingerol (GNL) to DOX within Liver Cancer Cells}

Chemomodulatory effect of gingerol to doxorubicin (DOX) within liver cancer cells was determined using combination analysis between DOX and GNL as previously described [63]. Briefly, exponentially growing HepG2 and Huh-7 cells were seeded in 96-well plates (2000 cells/well) and exposed to equitoxic concentrations of DOX and GNL for $72 \mathrm{~h}$. Cells were subsequently subjected to SRB assay as described in section 4.8. Combination index (CI-value) was calculated and used to define the nature of drug interaction (synergism if CI-value $<0.8$ as; antagonism if CI-value $>1.2$; and additive if CI-value ranges from 0.8-1.2). CI-value was calculated from the formula:

$$
\mathrm{CI}-\text { value }=\frac{\mathrm{IC}_{50} \operatorname{drug}(\mathrm{x}) \text { combination }}{\mathrm{IC}_{50} \mathrm{drug}(\mathrm{x}) \text { alone }}+\frac{\mathrm{IC}_{50} \mathrm{drug}(\mathrm{y}) \text { combination }}{\mathrm{IC}_{50} \mathrm{drug}(\mathrm{y}) \text { alone }}
$$

\subsection{Analysis of Cell Cycle Distribution}

To assess the effect of the doxorubcin, gingerol and their combination on cell cycle distribution, HepG2 and Huh-7 cells were treated with the pre-determined $\mathrm{IC}_{50} \mathrm{~s}$ of both agents for $24 \mathrm{~h}$. 
After treatment, cells were collected by trypsinization; washed twice with ice-cold PBS and re-suspended in $0.5 \mathrm{~mL}$ of PBS. Two milliliters of $70 \%$ ice-cold ethanol was added gently while vortexing. Cells were kept in ethanol solution at $4{ }^{\circ} \mathrm{C}$ for $1 \mathrm{~h}$ for fixation. Upon analysis, fixed cells were washed and re-suspended in $1 \mathrm{~mL}$ of PBS containing $50 \mu \mathrm{g} / \mathrm{mL}$ RNAase A and $10 \mu \mathrm{g} / \mathrm{mL}$ propidium iodide (PI). After $20 \mathrm{~min}$ incubation in dark place at room temperature, cells were analyzed for DNA contents by FACS-Vantage ${ }^{\mathrm{TM}}$ (Becton Dickinson Immunocytometry Systems). For each sample, 10,000 events were acquired. Cell cycle distribution was calculated using ACEA NovoExpress ${ }^{\mathrm{TM}}$ software (ACEA Biosciences Inc., San Diego, CA, USA).

\subsection{Animals}

Male Wistar rats (King Abdul-Aziz University, Jeddah, Saudi Arabia) weighing 120-140 g, aged 6 weeks were housed in clear polypropylene cages (three to four rats per cage) and kept under constant environmental conditions with equal light-dark cycle. Rats had free access to commercially available rodent pellet diet and purified water. All experimental procedures were performed in accordance with Saudi Arabia Research Bioethics and Regulations, which are consistent with the Guide for the Care and Use of Laboratory Animals published by the U.S. National Institutes of Health.

\subsection{Assessing the Protective Effect of 6-gingerol Against Doxorubicin Induced Vascular Damage}

To assess the protective effect of 6-gingerol on doxorubicin-induced vascular damage, deterioration in vascular reactivity was measured. Vascular reactivity of isolated thoracic aortae was determined using isolated artery techniques described in our previous publications $[64,65]$. Briefly, isolated aortae were co-incubated within organ bath with doxorubicin $(10 \mu \mathrm{M})$ with or without different concentrations of 6-gingerol $(0.3-30 \mu \mathrm{M})$ for $30 \mathrm{~min}$ before assessing the vasoconstriction and vasodilation responses compared to control aortic ring. For assessing the aortic contractile responsiveness, increases in tension due to cumulative additions of $P E\left(10^{-9}\right.$ to $\left.10^{-5} \mathrm{M}\right)$ were recorded and expressed as milligram tension. In order to study the vasodilator responsiveness, aortic rings were first pre-contracted with maximal concentrations of PE $\left(10^{-5} \mathrm{M}\right)$. Cumulative concentrations of ACh $\left(10^{-9}\right.$ to $\left.10^{-5} \mathrm{M}\right)$ were then added to the organ bath and responses were recorded as percentage in relation to PE pre-contraction.

\subsection{Statistical Analysis}

Data are presented as mean \pm SEM using GraphPad prism ${ }^{\mathrm{TM}}$ software (GraphPad Software Inc., La Jolla, CA, USA) for windows version 5.00. Analysis of variance (ANOVA) with Newman Keuls post hoc test was used for testing the significance using SPSS ${ }^{\circledR}$ for windows, version 17.0.0. $p<0.05$ was taken as a cut off value for significance.

\section{Conclusions}

In conclusion, gingerol, despite its relatively weak antioxidant properties, was found to protect from DOX-induced vascular damage, apparently not through its free radical scavenging mechanism. In addition, gingerol synergized the cytotoxic effects of DOX against liver cancer cells at pharmacodynamic level. The gingerol-induced chemomodulatory effect of doxorubicin was found to be independent on influencing P-gp efflux activity and cellular pharmacokinetics within liver cancer cells.

Supplementary Materials: Supplementary materials can be accessed at: http://www.mdpi.com/1420-3049/21/ 7/886/s1.

Acknowledgments: This project is funded by King Abdulaziz City of Science and Technology (KACST), Riyadh, Saudi Arabia, under grant No (AT-35-122). The authors, therefore, acknowledge with thanks KACST technical and financial support. 
Author Contributions: Ahmed M. Al-Abd, Ali M. El-Halawany and Hany M. El-Bassossy conceived and designed the experiments; Eman A. Alghamdi, Mohammed A. Baghdadi, Abdulmohsin J. Alamoudi, performed the experiments; Ahmed M. Al-Abd, Ali M. El-Halawany and Hany M. El-Bassossy analyzed the data; Fahad A. Al-Abbasi and Ali H. Aseeri contributed reagents/materials/analysis tools; Ahmed M. Al-Abd, Ali M. El-Halawany and Hany M. El-Bassossy wrote the paper.

Conflicts of Interest: The authors declare no conflict of interest.

\section{Abbreviations}

The following abbreviations are used in this manuscript:

\begin{tabular}{|c|c|}
\hline $\mathrm{ACh}$ & Acetylcholine \\
\hline $\mathrm{CCl}_{4}$ & Carbon tetrachloride \\
\hline DIACHEP (7) & 3,5-Diacetoxy-1-(3',4'-dihydroxylphenyl)-7-(3",4"-dihydroxy-5"-methoxyphenyl) heptane \\
\hline DOX & Doxorubicin \\
\hline GNL & Gingerol \\
\hline GSH & Glutathione (reduced form) \\
\hline GSSG & Glutathione (oxidized form) \\
\hline iu & International Unit \\
\hline P-gp & P-glycoprotein \\
\hline PE & Phenylephrin \\
\hline ROS & Reactive oxygen species \\
\hline VRP & Verapamil \\
\hline
\end{tabular}

\section{References}

1. Duke, J.A. CRC Handbook of Medicinal Spices; CRC Press: Boca Raton, FL, USA, 2002.

2. Akendengue, B.; Louis, A.M. Medicinal plants used by the Masango people in Gabon. J. Ethnopharmacol. 1994, 41, 193-200. [CrossRef]

3. Umukoro, S.; Ashorobi, B.R. Further pharmacological studies on aqueous seed extract of Aframomum melegueta in rats. J. Ethnopharmacol. 2008, 115, 489-493. [CrossRef] [PubMed]

4. Kamtchouing, P.; Mbongue, G.; Dimo, T.; Watcho, P.; Jatsa, H.; Sokeng, S. Effects of Aframomum melegueta and Piper guineense on sexual behaviour of male rats. Behav. Pharmacol. 2002, 13, 243-247. [CrossRef] [PubMed]

5. El-Halawany, A.M.; El Dine, R.S.; El Sayed, N.S.; Hattori, M. Protective effect of Aframomum melegueta phenolics against $\mathrm{CCl}_{4}$-induced rat hepatocytes damage; role of apoptosis and pro-inflammatory cytokines inhibition. Sci. Rep. 2014, 4. [CrossRef] [PubMed]

6. El-Halawany, A.M.; Hattori, M. Anti-oestrogenic diarylheptanoids from Aframomum melegueta with in silico oestrogen receptor alpha binding conformation similar to enterodiol and enterolactone. Food Chem. 2012, 134, 219-226. [CrossRef]

7. Seo, H.B.; Kwon, T.D.; Song, Y.J. The effect of ginger extract ingestion and swimming exercise on insulin resistance and skeletal muscle antioxidant capacity and apoptosis in hyperglycemic rats fed a high-fructose diet. J. Exerc. Nutr. Biochem. 2011, 15, 41-48. [CrossRef]

8. Surh, Y.-J. Molecular mechanisms of chemopreventive effects of selected dietary and medicinal phenolic substances. Mutat. Res. 1999, 428, 305-327. [CrossRef]

9. El-Bakly, W.M.; Louka, M.L.; El-Halawany, A.M.; Schaalan, M.F. 6-Gingerol ameliorated doxorubicin-induced cardiotoxicity: Role of nuclear factor kappa B and protein glycation. Cancer Chemother. Pharmacol. 2012, 70, 833-841. [CrossRef] [PubMed]

10. Tjendraputra, E.; Tran, V.H.; Liu-Brennan, D.; Roufogalis, B.D.; Duke, C.C. Effect of ginger constituents and synthetic analogues on cyclooxygenase-2 enzyme in intact cells. Bioorganic Chem. 2001, 29, 156-163. [CrossRef] [PubMed]

11. Oyagbemi, A.A.; Saba, A.B.; Azeez, O.I. Molecular targets of 6-gingerol: Its potential roles in cancer chemoprevention. Biofactors 2010, 36, 169-178. [CrossRef] [PubMed]

12. Suresh, K.; Manoharan, S.; Arokia Vijayaanand, M.; Sugunadevi, G. Chemopreventive and antioxidant efficacy of (6)-paradol in 7,12-dimethylbenz(a)anthracene induced hamster buccal pouch carcinogenesis. Pharmacol. Rep. 2010, 62, 1178-1185. [CrossRef]

13. Keum, Y.-S.; Kim, J.; Lee, K.H.; Park, K.K.; Surh, Y.-J.; Lee, J.M.; Lee, S.-S.; Yoon, J.H.; Joo, S.Y.; Cha, I.H. Induction of apoptosis and caspase-3 activation by chemopreventive 6-paradol and structurally related compounds in KB cells. Cancer Lett. 2002, 177, 41-47. [CrossRef] 
14. Lee, K.K.; Bahler, B.D.; Hofmann, G.A.; Mattern, M.R.; Johnson, R.K.; Kingston, D.G. Isolation and structure elucidation of new pkc $\alpha$ inhibitors from Pinus flexilis. J. Nat. Prod. 1998, 61, 1407-1409. [CrossRef] [PubMed]

15. Lee, K.-S.; Li, G.; Kim, S.H.; Lee, C.-S.; Woo, M.-H.; Lee, S.-H.; Jhang, Y.-D.; Son, J.-K. Cytotoxic diarylheptanoids from the roots of Juglans mandshurica. J. Nat. Prod. 2002, 65, 1707-1708. [CrossRef] [PubMed]

16. Novaković, M.; Pešić, M.; Trifunović, S.; Vučković, I.; Todorović, N.; Podolski-Renić, A.; Dinić, J.; Stojković, S.; Tešević, V.; Vajs, V. Diarylheptanoids from the bark of black alder inhibit the growth of sensitive and multi-drug resistant non-small cell lung carcinoma cells. Phytochemistry 2014, 97, 46-54. [CrossRef] [PubMed]

17. Torre, L.A.; Bray, F.; Siegel, R.L.; Ferlay, J.; Lortet-Tieulent, J.; Jemal, A. Global cancer statistics, 2012. CA Cancer J. Clin. 2015, 65, 87-108. [CrossRef] [PubMed]

18. Arcamone, F.; Cassinelli, G.; Fantini, G.; Grein, A.; Orezzi, P.; Pol, C.; Spalla, C. Adriamycin, 14-hydroxydaunomycin, a new antitumor antibiotic from s. Peucetius var. Caesius. Biotechnol. Bioeng. 1969, 11, 1101-1110. [CrossRef] [PubMed]

19. Vilaseca, J.; Guardia, J.; Bacardi, R.; Monne, J. Doxorubicin for liver cancer. Lancet 1978, 1, 1367. [CrossRef]

20. Maeng, J.H.; Lee, D.H.; Jung, K.H.; Bae, Y.H.; Park, I.S.; Jeong, S.; Jeon, Y.S.; Shim, C.K.; Kim, W.; Kim, J.; et al. Multifunctional doxorubicin loaded superparamagnetic iron oxide nanoparticles for chemotherapy and magnetic resonance imaging in liver cancer. Biomaterials 2010, 31, 4995-5006. [CrossRef] [PubMed]

21. Licata, S.; Saponiero, A.; Mordente, A.; Minotti, G. Doxorubicin metabolism and toxicity in human myocardium: Role of cytoplasmic deglycosidation and carbonyl reduction. Chem. Res. Toxicol. 2000, 13, 414-420. [CrossRef] [PubMed]

22. Von Hoff, D.D.; Layard, M.W.; Basa, P.; Davis, H.L., Jr.; Von Hoff, A.L.; Rozencweig, M.; Muggia, F.M. Risk factors for doxorubicin-induced congestive heart failure. Ann. Intern. Med. 1979, 91, 710-717. [CrossRef] [PubMed]

23. Asensio-Lopez, M.C.; Sanchez-Mas, J.; Pascual-Figal, D.A.; Abenza, S.; Perez-Martinez, M.T.; Valdes, M.; Lax, A. Involvement of ferritin heavy chain in the preventive effect of metformin against doxorubicin-induced cardiotoxicity. Free Radic. Biol. Med. 2012. [CrossRef] [PubMed]

24. Sakr, S.A.; El-Shenawy, S.M.; Al-Shabka, A.M. Aqueous fenugreek seed extract ameliorates adriamycin-induced cytotoxicity and testicular alterations in albino rats. Reprod. Sci. 2012, 19, 70-80. [CrossRef] [PubMed]

25. Kapuscinski, J.; Ardelt, B.; Piosik, J.; Zdunek, M.; Darzynkiewicz, Z. The modulation of the DNA-damaging effect of polycyclic aromatic agents by xanthines. Part I. Reduction of cytostatic effects of quinacrine mustard by caffeine. Biochem. Pharmacol. 2002, 63, 625-634. [CrossRef]

26. Greenlee, H.; Shaw, J.; Lau, Y.K.; Naini, A.; Maurer, M. Lack of effect of coenzyme Q10 on doxorubicin cytotoxicity in breast cancer cell cultures. Integr. Cancer Ther. 2012, 11, 243-250. [CrossRef] [PubMed]

27. Al-Abd, A.M.; Al-Abassi, F.A.; Asaad, G.F.; Abdel-Naim, A.B. Didox potentiates the cytotoxic profile of doxorubicin and protects from its cardiotoxicity. Eur. J. Pharmacol. 2013, 718, 361-369. [CrossRef] [PubMed]

28. Al-Abd, A.M.; Mahmoud, A.M.; El-Sherbiny, G.A.; El-Moselhy, M.A.; Nofal, S.M.; El-Latif, H.A.; El-Eraky, W.I.; El-Shemy, H.A. Resveratrol enhances the cytotoxic profile of docetaxel and doxorubicin in solid tumour cell lines in vitro. Cell Prolif. 2011, 44, 591-601. [CrossRef] [PubMed]

29. Sun, H.; Liu, X.D.; Liu, Q.; Wang, F.P.; Bao, X.Q.; Zhang, D. Reversal of P-glycoprotein-mediated multidrug resistance by the novel tetrandrine derivative W6. J. Asian Nat. Prod. Res. 2015, 17, 638-648. [CrossRef] [PubMed]

30. Abdallah, H.M.; Al-Abd, A.M.; El-Dine, R.S.; El-Halawany, A.M. P-glycoprotein inhibitors of natural origin as potential tumor chemo-sensitizers: A review. J. Adv. Res. 2015, 6, 45-62. [CrossRef] [PubMed]

31. Jiang, H.; Timmermann, B.N.; Gang, D.R. Characterization and identification of diarylheptanoids in ginger (Zingiber officinale rosc.) using high-performance liquid chromatography/electrospray ionization mass spectrometry. Rapid Commun. Mass Spectrom. 2007, 21, 509-518. [CrossRef] [PubMed]

32. Ma, S.; Zhang, S.; Duan, W.; Wang, W. An enantioselective synthesis of (+)-(S)-[n]-gingerols via the L-proline-catalyzed aldol reaction. Bioorg. Med. Chem. Lett. 2009, 19, 3909-3911. [CrossRef] [PubMed]

33. Escoubas, P.; Lajide, L.; Mizutani, J. Termite antifeedant activity in Aframomum melegueta. Phytochemistry 1995, 40, 1097-1099. [CrossRef]

34. Tackie, A.; Dwuma-Badu, D.; Ayim, J.; Dabra, T.; Knapp, J.; Slatkin, D.; Schiff, P. Hydroxyphenylalkanones from Aframomum melegueta. Phytochemistry 1975, 14, 853-854. [CrossRef] 
35. Jolad, S.D.; Lantz, R.C.; Chen, G.J.; Bates, R.B.; Timmermann, B.N. Commercially processed dry ginger (Zingiber officinale): Composition and effects on LPS-stimulated PGE 2 production. Phytochemistry 2005, 66, 1614-1635. [CrossRef] [PubMed]

36. Dev, S. Impact of natural products in modern drug development. Indian J. Exp. Biol. 2010, 48, 191-198. [PubMed]

37. Aboul-Enein, A.M.; Al-Abd, A.M.; Shalaby, E.; Abul-Ela, F.; Nasr-Allah, A.A.; Mahmoud, A.M.; El-Shemy, H.A. Eichhornia crassipes (mart) solms: From water parasite to potential medicinal remedy. Plant Signal. Behav. 2011, 6, 834-836. [CrossRef] [PubMed]

38. Ibrahim, S.R.M.; Abdallah, H.M.; El-Halawany, A.M.; Mohamed, G.A. Naturally occurring thiophenes: Isolation, purification, structural elucidation, and evaluation of bioactivities. Phytochem. Rev. 2015, 15, 197-220. [CrossRef]

39. Cragg, G.M.; Grothaus, P.G.; Newman, D.J. Impact of natural products on developing new anti-cancer agents. Chem. Rev. 2009, 109, 3012-3043. [CrossRef] [PubMed]

40. Hassan, H.M.; Elnagar, A.Y.; Khanfar, M.A.; Sallam, A.A.; Mohammed, R.; Shaala, L.A.; Youssef, D.T.A.; Hifnawy, M.S.; El Sayed, K.A. Design of semisynthetic analogues and 3D-QSAR study of eunicellin-based diterpenoids as prostate cancer migration and invasion inhibitors. Eur. J. Med. Chem. 2011, 46, 1122-1130. [CrossRef] [PubMed]

41. Heim, K.E.; Tagliaferro, A.R.; Bobilya, D.J. Flavonoid antioxidants: Chemistry, metabolism and structure-activity relationships. J. Nutr. Biochem. 2002, 13, 572-584. [CrossRef]

42. Natella, F.; Nardini, M.; Di Felice, M.; Scaccini, C. Benzoic and cinnamic acid derivatives as antioxidants: Structure-activity relation. J. Agric. Food Chem. 1999, 47, 1453-1459. [CrossRef] [PubMed]

43. Selassie, C.D.; Kapur, S.; Verma, R.P.; Rosario, M. Cellular apoptosis and cytotoxicity of phenolic compounds: A quantitative structure-activity relationship study. J. Med. Chem. 2005, 48, 7234-7242. [CrossRef] [PubMed]

44. Ghareib, S.A.; El-Bassossy, H.M.; Elberry, A.A.; Azhar, A.; Watson, M.L.; Banjar, Z.M. 6-Gingerol alleviates exaggerated vasoconstriction in diabetic rat aorta through direct vasodilation and nitric oxide generation. Drug Des. Dev. Ther. 2015, 9, 6019-6026.

45. Chen, Y.L.; Zhuang, X.D.; Xu, Z.W.; Lu, L.H.; Guo, H.L.; Wu, W.K.; Liao, X.X. Higenamine combined with 6-gingerol suppresses doxorubicin-triggered oxidative stress and apoptosis in cardiomyocytes via upregulation of PI3K/Akt pathway. Evid. Based Complement. Altern. Med. 2013, 2013, 970490. [CrossRef] [PubMed]

46. Krishna, R.; Mayer, L.D. Multidrug resistance (MDR) in cancer. Mechanisms, reversal using modulators of $\mathrm{mdr}$ and the role of MDR modulators in influencing the pharmacokinetics of anticancer drugs. Eur. J. Pharm. Sci. 2000, 11, 265-283. [CrossRef]

47. Nakumura, T.; Sakaeda, T.; Ohmoto, N.; Moriya, Y.; Komoto, C.; Shirakawa, T.; Gotoh, A.; Matsuo, M.; Okmura, K. Gene expression profiles of ABC transporters and cytochrome P450 3A in CaCo-2 and human colorectal cancer cell lines. Pharm. Res. 2003, 20, 324-327. [CrossRef] [PubMed]

48. Leonard, G.D.; Fojo, T.; Bates, S.E. The role of ABC transporters in clinical practice. Oncologist 2003, 8, 411-424. [CrossRef] [PubMed]

49. Liu, Z.; Duan, Z.J.; Chang, J.Y.; Zhang, Z.F.; Chu, R.; Li, Y.L.; Dai, K.H.; Mo, G.Q.; Chang, Q.Y. Sinomenine sensitizes multidrug-resistant colon cancer cells (Caco-2) to doxorubicin by downregulation of $m d r-1$ expression. PLoS ONE 2014, 9, e98560. [CrossRef] [PubMed]

50. Van der Bliek, A.M.; Baas, F.; Ten Houte de Lange, T.; Kooiman, P.M.; Van der Velde-Koerts, T.; Borst, P. The human $M d r 3$ gene encodes a novel P-glycoprotein homologue and gives rise to alternatively spliced mRNAs in liver. EMBO J. 1987, 6, 3325-3331. [PubMed]

51. Behling, E.B.; Sendao, M.C.; Francescato, H.D.; Antunes, L.M.; Costa, R.S.; Bianchi Mde, L. Comparative study of multiple dosage of quercetin against cisplatin-induced nephrotoxicity and oxidative stress in rat kidneys. Pharmacol. Rep. 2006, 58, 526-532. [PubMed]

52. Topal, T.; Oztas, Y.; Korkmaz, A.; Sadir, S.; Oter, S.; Coskun, O.; Bilgic, H. Melatonin ameliorates bladder damage induced by cyclophosphamide in rats. J. Pineal Res. 2005, 38, 272-277. [CrossRef] [PubMed]

53. Li, X.Q.; Wang, L.; Lei, Y.; Hu, T.; Zhang, F.L.; Cho, C.H.; To, K.K. Reversal of P-gp and BCRP-mediated MDR by tariquidar derivatives. Eur. J. Med. Chem. 2015, 101, 560-572. [CrossRef] [PubMed]

54. Klimaszewska-Wisniewska, A.; Halas-Wisniewska, M.; Tadrowski, T.; Gagat, M.; Grzanka, D.; Grzanka, A. Paclitaxel and the dietary flavonoid fisetin: A synergistic combination that induces mitotic catastrophe 
and autophagic cell death in A549 non-small cell lung cancer cells. Cancer Cell Int. 2016, 16, 10. [CrossRef] [PubMed]

55. Songgang, L.; Jiyu, L.; Gongwei; Yingbin, L.; Yiyu, Q.; Zhiwei, Q. Somatostatin enhances the chemosensitivity of GBC-SD cell line to doxorubicin through arresting the cell cycle to $S$ phase rather than through the P53/Bax-depended apoptosis way in vitro. Hepato Gastroenterol. 2009, 56, 1253-1260.

56. Ehrhardt, H.; Pannert, L.; Pfeiffer, S.; Wachter, F.; Amtmann, E.; Jeremias, I. Enhanced anti-tumour effects of vinca alkaloids given separately from cytostatic therapies. Br. J. Pharmacol. 2013, 168, 1558-1569. [CrossRef] [PubMed]

57. Huang, J.J.; Li, Z.M.; Huang, Y.; Huang, Y.; Tian, Y.; He, X.X.; Xiao, J.; Lin, T.Y. Schedule-dependent inhibition of T-cell lymphoma cells by cotreatment with the mTOR inhibitor everolimus and anticancer drugs. Investig. New Drugs 2012, 30, 223-235. [CrossRef] [PubMed]

58. Beutler, E.; Duron, O.; Kelly, B.M. Improved method for the determination of blood glutathione. J. Lab. Clin. Med. 1963, 61, 882-888. [PubMed]

59. Melissinos, K.G.; Delidou, A.Z.; Varsou, A.G.; Begietti, S.S.; Drivas, G.J. Serum and erythrocyte glutathione reductase activity in chronic renal failure. Nephron 1981, 28, 76-79. [CrossRef] [PubMed]

60. Prohaska, J.R.; Oh, S.H.; Hoekstra, W.G.; Ganther, H.E. Glutathione peroxidase: Inhibition by cyanide and release of selenium. Biochem. Biophys. Res. Commun. 1977, 74, 64-71. [CrossRef]

61. Skehan, P.; Storeng, R.; Scudiero, D.; Monks, A.; McMahon, J.; Vistica, D.; Warren, J.T.; Bokesch, H.; Kenney, S.; Boyd, M.R. New colorimetric cytotoxicity assay for anticancer-drug screening. J. Natl. Cancer Inst. 1990, 82, 1107-1112. [CrossRef] [PubMed]

62. Mahmoud, A.M.; Al-Abd, A.M.; Lightfoot, D.A.; El-Shemy, H.A. Anti-cancer characteristics of mevinolin against three different solid tumor cell lines was not solely P53-dependent. J. Enzyme Inhib. Med. Chem. 2012, 27, 673-679. [CrossRef] [PubMed]

63. Chou, T.C.; Talalay, P. Quantitative analysis of dose-effect relationships: The combined effects of multiple drugs or enzyme inhibitors. Adv. Enzyme Regul. 1984, 22, 27-55. [CrossRef]

64. El-Bassossy, H.M.; El-Moselhy, M.A.; Mahmoud, M.F. Pentoxifylline alleviates vascular impairment in insulin resistance via TNF-alpha inhibition. Naunyn Schmiedebergs Arch. Pharmacol. 2011, 384, 277-285. [CrossRef] [PubMed]

65. El-Bassossy, H.M.; El-Fawal, R.; Fahmy, A. Arginase inhibition alleviates hypertension associated with diabetes: Effect on endothelial dependent relaxation and no production. Vasc. Pharmacol. 2012, 57, 194-200. [CrossRef] [PubMed]

Sample Availability: Samples of all compounds are available from the authors.

(C) 2016 by the authors; licensee MDPI, Basel, Switzerland. This article is an open access article distributed under the terms and conditions of the Creative Commons Attribution (CC-BY) license (http:/ / creativecommons.org/licenses/by/4.0/). 